\title{
GRAFFITI BERBAHASA MINANGKABAU \\ PADA ANGKUTAN KOTA \\ DI KOTA PADANG
}

\section{Zilda Alamanda}

\begin{abstract}
This article describes lingual forms, function, and meaning of graffiti on mass transportation in Padang. On this research, data was obtained from interview with the drivers and co drivers. The result shows there are three lingual forms (word, phrase, and sentence), seven functions (instrumental, regulatory, representational, interactional, personal, heuristic, and imaginative), and three meaning (lexical, grammatical, and contextual) on the objects.
\end{abstract}

Key word: graffiti, Padang, bentuk lingual, transportasi umum

\section{Pengantar}

Bahasa adalah alat komunikasi dan sebagai sarana untuk berperan, berekspresi, berinteraksi, menyampaikan ide dan melakukan proses transmisi budaya kepada generasi berikutnya yang digunakan oleh kelompok manusia atau masyarakat. Hal ini sejalan dengan pendapat Sapir (1921: 8) yang mengatakan bahasa adalah metode atau alat penyampaian ide, perasaan, dan keinginan. Bahasa juga sebagai penanda yang jelas dari kepribadian manusia, penanda budayanya, dan juga sebagai penanda dari keluarga dan bangsa serta tanda dari budi kemanusiaan manusia sebagai makhluk sosial.

Bahasa menjadi sebuah bentuk produk sosial atau budaya, bahkan merupakan bagian tak terpisahkan dari kebudayaan yang melahirkan keberagaman berbahasa. Bahasa juga merupakan alat untuk mengungkap dan mengekpresikan makna budaya suatu kelompok sosial dan masyarakat sekelilingnya. Pengungkapan makna budaya melalui bahasa setiap individu

WACANA ETNIK, Jurnal IImu Sasial dan Humaniara. ISSN 2098-8746.

Volume 1, Nomor 2, Oktober 2010. Halaman 129 - 140. 
maupun kelompok akan berbeda satu sama lainnya yang akan melahirkan keberagaman dalam berbahasa.

Perkembangan zaman dan budaya akan mempengaruhi bahasa, yang akan dimunculkan dalam cara pengungkapannya yang beragam. Salah satu bentuk dari pengungkapan bahasa yang beragam, dapat dilihat dari bentuknya yang berupa ekspresi tulisan dan gambar yang berkreasi seni yang disebut dengan graffiti. Ekspresi tulis ini merupakan kondisi pembentukan model budaya untuk mencurahkan kreatifitas berbahasa seseorang maupun kelompok sosial.

Graffiti adalah sebuah kegiatan seni yang menggunakan garis, pola, bentuk dan memainkan keterpaduan warna yang menuliskan teks maupun tulisan dan gambar di atas dinding, kertas, papan, kain bahkan juga pada badan-badan mobil maupun kendaraan umum (Gumilang, 2008: 1 dan 2). Graffiti yang berasal dari bahasa Yunani graphein (menuliskan), diartikan sebagai coretan pada dinding atau permukaan di tempat-tempat umum, atau tempat pribadi, coretan tersebut bentuknya bisa berupa tulisan, gambar, sandi-sandi atau hanya berupa kata-kata yang umumnya hanya dipahami oleh kelompok-kelompok tertentu.

Pada awalnya, seni graffiti atau corat-coret ini digunakan sebagai salah satu bentuk-bentuk protes kepada dunia politik atau apapun lewat coretan di tembok pinggir jalan. Namun, dalam perkembangannya aksi ini malah berubah fungsi menjadi seni. Graffiti itu sendiri berfungsi sebagai bahasa rahasia kelompok tertentu, sarana ekpresi ketidakpuasan terhadap keadaan sosial, sarana pemberontakan dan dan sarana ekspresi ketakutan terhadap kondisi politik dan sosial (Bambataa, 2006: 32).

Seni graffiti bahasa yang digunakan umumnya adalah bahasa yang dapat mengekspresikan diri dan mewakili ungkapan perasaan yang dipasang pada angkot yang dapat ditemui di Kota Padang. Makna dan referen dalam tulisan tersebut tentunya akan berhubungan erat sekali dengan kondisi sosial pembuat dari graffiti itu sendiri yang tidak lain adalah para sopir angkot tentunya. Hal ini memperlihatkan kreativitas para penggunanya dalam menggunakan kata-kata yang bersifat umum, menjadi suatu yang bisa mewakili perasaan mereka.

Penelitian ini dikhususkan kepada graffiti yang berbahasa Minangkabau, karena akan lebih mudah mengenali dan memahami kondisi sosial seseorang melalui bahasa dalam budayanya. Faktor budaya mempengaruhi bahasa yang digunakan, karena pengguna dan pemakai 
graffiti hidup dalam konteks budaya Minangkabau maka bahasa yang digunakan umumnya adalah bahasa Minangkabau. Hal ini dilakukan agar pesan dan ungkapan perasaan dapat disampaikan secara keseluruhan dipahami oleh masyarakat yang memiliki budaya yang sama.

Hal lain yang membuat tertarik untuk memilih penelitian terhadap graffiti ini adalah untuk menemukan motivasi para pembuat graffiti. Peneliti tertarik untuk menguak lebih mendalam tentang kondisi sosial yang melatari lahirnya graffiti. Dengan memperhatikan bahasa yang digunakan dan dikaitkan dengan kondisi kemasyarakatannya. Jadi, yang dimaksud dalam penelitian ini adalah upaya mengetahui harapan-harapan, anganangan, ilusi dan keinginan ideal yang ingin diwujudkan, melalui tulisan yang dititikberatkan pada angkot di Kota Padang.

\section{Kerangka Teoretis}

Bidang linguistik yang disebut bidang studi pemakaian bahasa merupakan bagian terbesar dari pembahasan dalam bidang studi bahasa yang dikaitkan dengan kondisi sosial masyarakat yang disebut sosiolinguistik. Dengan demikian, penelitian graffiti dalam bahasa Minangkabau termasuk ke dalam penelitian sosiolinguistik, karena hal utama yang dibicarakan di sini adalah pemakaian bahasa yang disesuaikan menurut konteks penggunanya. Sosiolinguistik merupakan gabungan dari dua bidang ilmu yang berbicara tentang bahasa (linguistik) dan tentang sosial/masyarakat (Mahsun, 2005: 202).

Menurut Sumarsono (2002: 1), sosiolinguistik adalah kajian tentang bahasa yang dikaitkan dengan kondisi kemasyarakatan. Fishman dalam Sumarsono (2002), sosiolinguistik menyoroti keseluruhan masalah yang berhubungan dengan organisasi sosial perilaku bahasa, tidak hanya mencakup pemakaian bahasa saja, melainkan juga sikap-sikap bahasa pada pemakai bahasa itu sendiri.

Kajian sosiolinguistik menitikberatkan peran bahasa sebagai media untuk menyampaikan pesan dan mempertemukan pemahaman terhadap perbedaan ragam tutur dalam masyarakat. Tujuannya agar dicapai kesamaan pemahaman agar terciptanya tatanan sosio-kultural yang baik. Analisis sosiolinguistik merupakan upaya dalam mengkaji fungsi sosial bahasa. Penelitian tentang graffiti ini ditujukan untuk memberikan argumentasi tentang adanya makna sosial dalam pemakaian bahasa oleh para pemakai graffiti itu sendiri. 
Sementara itu, pragmatik dapat didefinisikan sebagai cabang ilmu linguistik mengenai tujuan ujaran dalam situasi tertentu. Pragmatik berbeda dengan semantik dalam hal pragmatik mengkaji maksud ujaran dengan satuan analisisnya berupa tindak tutur (speech act), sedangkan semantik menelaah makna satuan lingual (kata atau kalimat) dengan satuan analisisnya berupa arti atau makna.

Pengertian pragmatik adalah keterampilan menggunakan bahasa sesuai dengan konteksnya, baik konteks sosial, maupun konteks budaya dengan mengingat faktor penentunya (Lubis, 2007: 13).

Analisis pragmatik ini memiliki jangkauan kajian yang lebih luas dan dalam, yakni mencakup tindakan, konteks, historis, kekuasaan, dan ideologi, Cakupan kajian pragmatik yang sangat luas sering dianggap tumpang tindih dengan kajian wacana atau kajian sosiolinguistik. Yang jelas disepakati ialah bahwa satuan kajian pragmatik bukanlah kata atau kalimat, melainkan tindak tutur atau tindak ujaran (speech act) (Levinson, 1987: 1-53).

Dalam konteks makro, penelitian ini termasuk penelitian sosiolinguistik, sedangkan dalam konteks mikro, penelitian ini termasuk dalam penelitian pragmatik. Dikatakan demikian, karena penelitian ini lebih memfokuskan makna tutur secara nonliteral dan terikat konteks interaksi antara sopir dengan penumpang, majikannya, sesama sopir dan dengan siapa saja ia ingin bicara.

Dari segi sosiolinguistik, penelitian ini diharapkan dapat digunakan untuk memahami makna bahasa yang disampaikan sopir. Dari segi kajian pragmatik, penelitian ini diharapkan dapat menghasilkan deskripsi tentang bentuk makna.

Seperti yang telah diuraikan, pemaknaan graffiti dipengaruhi oleh konteks yang menyertai terjadinya sebuah bahasa tulisan. Konteks pesan dalam graffiti yang berbeda dapat menimbulkan makna yang berbeda-beda pula.

Konteks yang dimaksud di atas meliputi penutur, mitra tutur, waktu, tempat, adegan, topik, peristiwa, bentuk amanat, kode, dan saluran. Unsurunsur itu berhu-bungan pula dengan unsur-unsur yang terdapat dalam setiap komunikasi bahasa, antara lain dikemukakan oleh Hymes dalam Nababan (1993: 7) yang tercakup dalam akronim SPEAKING. Kepanjangan SPEAKING adalah setting atau scene (latar), participants (peserta tutur), ends (hasil), act sequences (urutan tidak), key (cara), instrumentalities (sarana), 
norms (norma), dan genre (jenis).

Penggabungan dua kajian yaitu sosiolinguistik dan pragmatik ini dapat disebut dengan sosiopragmatik. Sosiopragmatik adalah cabang ilmu linguistik yang mengkaji bahasa dengan pendekatan sosial dan pragmatik (Agusti, 2002: 5).

\section{Metodologi}

Populasi dalam penelitian ini adalah seluruh graffiti yang ada pada angkutan umum di Kota Padang. Sampelnya yaitu graffiti dalam bahasa Minangkabau yang terdapat pada angkutan kota (selanjutnya disingkat angkot) di Kota Padang. Jurusan angkot ini ada dari berbagai daerah yaitunya dari Pasar Raya, Tabiang, Lubuak Buayo, Labor, Pengambiran, Lubeg, Indaruang, Gaduik, Aua Duri, Jati, Siteba, Lapai, Balai Baru, Pasar Baru, Balimbiang, Kalawi, Pisang dan lainnya. Peneliti mengambil beberapa sampel dari masing-masing jurusan untuk memudahkan peneliti dalam mengumpulkan data. Penelitian ini dilakukan selama 5 bulan, dimulai dari bulan Agustus sampai dengan bulan Desember 2009. Peneliti beranggapan penelitian yang dilakukan selama 5 (lima) bulan ini sudah representatif untuk dianalisis.

Pengumpulan data dilakukan dengan metode cakap dengan menggunakan teknik pancing dan metode simak libat cakap, teknik rekam dan catat. Teknik pancing pada metode simak ini digunakan untuk menggali data dari nara sumber yang tidak lain adalah para pengguna atau pemakai graffiti dalam bentuk bahasa Minangkabau. Penggunaan metode simak dengan memakai teknik wawancara dan teknik rekam sekaligus dicatat. Ada kecenderungan informasi yang didapat diragukan kebenarannya. Oleh karena itu, untuk mendapatkan data yang lebih dapat intens lagi, peneliti dalam mengumpulkan data menggunakan mediator. Mediator atau orang ketiga ini berfungsi sebagai penguji kebenaran data yang diperoleh sebelumnya.

Untuk analisis data akan digunakan metode padan dengan menggunakan teknik ortografis, pragmatis dan translasional. Teknik ortografis pada metode padan ini digunakan karena objek dari penelitian ini adalah tulisan itu sendiri (graffiti). Teknik pragmatis digunakan pada metode padan adalah untuk mengetahui pemaknaan dari tulisan kepada mitra wicara atau kepada siapa tulisan itu ditujukan. Teknik translasional digunakan untuk mengalih bahasakan dari bahasa Minangkabau kepada 
bahasa Indonesia. Selanjutnya, metode agih digunakan sebagai penentu satuan lingual seperti kata, frasa, dan kalimat.

\section{Graffiti Berbahasa Minangkabau: Bentuk, Fungsi, dan Makna}

Berdasarkan bentuk-bentuk lingual yang ditemukan, bentuk graffiti berada pada tataran lingual satuan kata, kelompok kata, dan kalimat.

$$
\begin{aligned}
& \text { Palano } \\
& \text { pelana }
\end{aligned}
$$

Data (1), kata palano merupakan nomina dasar, dalam KUBM (Usman, 1985: 725) adalah pelana. palano yaitu lapik pada punggung kuda dsb; tempat duduk orang yang menunggang kuda. Makna dari kata palano adalah para sopir angkot beranggapan bahwa mereka adalah pelana bagi majikan. Mereka adalah alat dan majikan yang mengendalikannya.

(4) Rhesex

meraba yang tak tentu arah dan sasaran

Data (4) kata yang dimaksudkan sopir di sini adalah kata resek, penambahan huruf ' $h$ ' dan ' $x$ ' pada akhiran kata merupakan seni dalam graffiti saja. Resek merupakan kata verba dalam KUBM (Usman, 2002: 469) berarti raba. Kata ini berhubungan dengan kepribadian sopir angkot yang kebanyakan masih muda, yang rasa penasaran dan semangat yang tinggi dalam mencari penumpang. Resek yang dimaksud adalah sopir akan meraba-raba kemana yang ia rasa ada orang yang akan menumpang selagi tidak jauh dari jalur jalan yang telah ditentukan.

Lesex lasak

Pada data (7) akhir kata lesek diberi huruf ' $x$ ', seharusnya adalah ' $k$ ', tujuan sopir mengganti huruf ini, hanya untuk menjadikan kata tersebut lebih bervariasi saja. Lesek dalam KUBM (Usman, 2002: 367) berarti lasak; roseng; tidak tenang (tangan, kaki, selalu bergerak, memegang, memindahkan atau mengerjakan apa saja, pantat tidak dapat duduk lama, tidur tidak tenang dan selalu gelisah). Lesek merupakan kata adjektiva dasar merupakan sebutan kepada penumpang yang suka tidak tenang duduk di 
dalam angkot dan suka bergerak tidak menentu dan suka pindah-pindah ke sana ke mari yang membuat sopir dan penumpang lainnya tidak nyaman.

$$
\begin{aligned}
& \text { Nan mujua } \\
& \text { yang beruntung }
\end{aligned}
$$

Pada data (13), nan mujua adalah sebuah frasa untuk dituliskan apabila si sopir angkot, tumpangannya hanya sedikit bahkan terkadang kosong. Sewaktu ia melihat ada angkot yang selalu berisi penumpang dan seringkali penuh, nasibnya sedang beruntung. Maka si sopir itu adalah orang yang beruntung dari yang lainnya.

$$
\begin{aligned}
& \text { Raso-raso kalai } \\
& \text { mungkin bisa }
\end{aligned}
$$

Data (15), seringkali sopir dilontarkan pertanyaan baik itu oleh penumpang maupun orang lain di luar profesinya sebagai sopir angkot. Pertanyaan itu menyangkut apakah penghasilan menjadi sopir angkot dapat memenuhi kebutuhan keluarga mereka. Sebagian dari mereka akan menjawab dengan raso-raso kalai, yang dimaksud di sini bagi sebagian sopir berpikir bisa saja menghidupi keluarga dengan menjadi seorang sopir angkot kalau selalu bekerja keras. Bisa saja tidak, kalau bekerja malasmalasan. Jadi, pekerjaan apa saja yang ditekuni bisa memenuhi kebutuhan hidup sekeluarga, bisa tidak mencukupi kalau bekerja dengan tidak sungguh-sungguh.

(19) Dek indak mangko co iko. karena tidak ada uang makanya hidup seperti ini

Pada data (19), perekonomian sopir bisa dikatakan banyak yang pas-pasan. Begitu juga dengan rumah, pakaian dan gaya hidup mereka juga terkesan biasa-biasa saja. Kalimat ini menggambarkan keadaan sopir adalah orang yang tidak berpunya dan tidak memiliki uang yang banyak maka kehidupan para sopir sangatlah biasa saja.

(20) Bantuak ndak tau se.

seperti tidak tahu saja

Data (20) merupakan kalimat yang ditujukan kepada sesama sopir 
angkot yang memiliki majikan yang sama. Terkadang majikan pada waktu yang tertentu akan marah-marah tidak menentu kepada anak buahnya. Ada salah satu anak buah yang menanggapi itu dengan serius. Si sopir akan mangatakan bahwa sifat dan karakter dari majikannya memang seperti itu dan hal itu sudah biasa terjadi. Hampir semua anak buah mendapat perlakuan seperti ini. Oleh karena ada teman sesama sopir yang menangggapi sikap dan perlakuan majikan dengan serius, maka si sopir akan menenangkan temannya bahwa sebagai anak buah harus memahami, karena nantinya majikan juga akan baik dengan sendirinya. Jadi, kalimat bantuak indak tau se yang berarti 'seperti tidak tau saja' perangai majikan ini, diangggap tepat untuk membuat teman untuk menanggapi majikan dengan sikap sewajarnya saja dan tidak usah ditangggapi dengan serius.

Dari analisis penggolongan fungsi dapat ditemukan ada tujuh fungsi bahasa graffiti, yaitunya instrumental, regulatory, representasional, interactional, personal, heuristic, dan imaginative.

(25) Papex

rata

Data (25) kata papex berasal dari kata papek, untuk dijadikan lebih menarik sopir mangganti huruf ' $k$ ' dengan ' $x$ '. Kata papek yang berarti rata, dipakai sebagai penanda bahwa seorang sopir akan menyamakan siapa saja penumpangnya dan tidak memilih-milih. Semua penumpang mendapat bagian yang sama tanpa ada membedakannya dengan yang lain. Baik itu tempat duduk maupun ongkos yang dibayarkan penumpang sama saja. Sopir dalam bekerja dan melakukan sesuatu kepada penumpang akan bersikap sama rata saja dengan yang lain tanpa ada yang dibedakan. Bahasa digunakan sebagai alat untuk menyampaikan dan melakukan sesuatu instrumental

(28) Ba'a lai talok?

Apakah berani?

Data (28) digunakan sopir untuk mempengaruhi lawannya sesama sopir. Untuk mendapatkan penumpang dan mencari penghasilan sebanyak-banyaknya maka sopir itu satu sama lain akan berpacu dan saling mendahului agar mendapat sewa yang banyak. Kecepatan angkot ini sudah dimodifikasi sedemikian rupa agar larinya lebih kencang. Angkot- 
angkot yang memiliki kecepatan, mesin dan tampilan bagus, biasanya akan meremehkan lawannya tersebut. Dalam kalimat ini digambarkan untuk mempertanyakan angkot yang lain tersebut, yang berani melawan kelebihannya. Sebenarnya ini hanyalah sebuah ancaman bagi yang lain, bahwa siapa yang larinya lebih kencang dan tampilan mobil yang bagus akan mudah saja mendapatkan penumpang. Bahasa digunakan untuk mempengaruhi lawan bicara. regulatory

(32) Paik-paik pario

biarpun susah tapi ditempuh juga

Data (32) maksudnya adalah biarpun berat tapi harus dilakukan juga. Pekerjaan sebagai sopir terkadang tidaklah mudah. Pekerjaan ini merupakan pekerjaan yang membosankan dan banyak kendala yang harus dihadapi, baik itu dengan sesama sopir maupun dengan majikan. Di sisi lain banyak juga hal yang membuat mereka bertahan dan betah untuk menjalani profesi sebagai sopir. Inilah fakta hidup yang harus mereka jalani sebagai seorang sopir. Bahasa digunakan untuk menyampaikan pernyataan representasional

\section{Mantiak}

genit

'Sejenis ilmu tentang cara berpikir logika dan retorika yang sejalan dengan ilmu ma'ani dan bayan, diperlukan dalam belajar membaca, menulis dan mengartikan bahasa arab; bijak karna ilmunya yang dalam; banyak bicara karena banyak kemampuannya dalam KUBM(Usman, 2002: 394).

Pada data (40), mantiak ditujukan kepada penumpang perempuan yang sering digoda oleh sopir. Kata ini juga ditujukan kepada penumpang yang menggoda sopir angkot. Pada contoh gambar di atas ada dua macam bentuk penulisan graffiti yang berbeda. Dapat kita lihat dengan kata yang sama, macam atau bentuk graffiti bisa berbentuk apa saja, tergantung kepada kreatifitas penulisnya saja membentuk huruf-huruf menjadi lebih menarik. Bahasa mengekspresikan perasaan dan kepribadian dari penggunanya personal

\section{Pameo}

'Kiasan atau nasehat atau istilah yang biasa digunakan oleh masyarakat untuk mengungkapkan sesuatu yang tidak bisa 
disampaikan melalui bahasa yang sebenarnya.'

Pada data (43) kata pameo yang digunakan oleh pemakai graffiti sebagai nama perkumpulan dan persatuan sopir angkot masing-masing jurusan. Kata pameo ini sendiri berarti istilah yang berisikan kiasan dan nasehat. Bahasa dipakai untuk mempelajari dan memperoleh pengetahuan heuristic

(44) Qapagulo

sebutan untuk orang yang banyak uang/orang kaya

Data (44) bacaannya adalah kapagulo, huruf ' $\mathrm{k}$ ' diganti dengan ' $\mathrm{q}$ ', karena menurut sopir bacaan dari kedua huruf ini hampir sama. Kapagulo adalah sebutan untuk orang kaya. Kata ini dipakai oleh sopir kepada majikannya yang mengatakan bahwa majikannya adalah orang yang banyak uang. Bahasa dapat melahirkan suatu gagasan dan imaginasi dari penggunanya imaginative

Setelah dilakukan pengklasifikasian terhadap data. Maka, makna pada graffiti ini dapat dibagi menjadi tiga, yaitu: pertama makna leksikal adalah makna yang sebenarnya, sesuai dengan observasi dan sesuai dengan makna pada kamus tanpa memperhatihan konteksnya. Kedua, makna gramatikal adalah makna yang hadir sebagai akibat adanya proses gramatikal. Maksudnya, makna yang didasarkan atas hubungan antara unsur satuan bahasa dengan satuan bahasa yang lebih besar. Berikut ini data yang memiliki makna gramatikal. Ketiga, makna Kontekstual adalah makna yang didasarkan atas hubungan antara ujaran dan situasi pemakaian ujaran. Berikut ini dapat kita lihat makna-makna tersebut.

(48) Ndak bara bedadoh!

tidak jauh berbeda

Data (48) ini memiliki makna leksikal. Sopir angkot saling mengadakan komunikasi sewaktu membawa angkot, tentang bagaimana hasil pencaharian sehari-hari. Apakah penumpang mereka banyak dan dapat setoran yang lebih. Namun, terkadang ada salah seorang di antara mereka yang kurang beruntung dan lainnya juga begitu. Saat teman yang lain mengeluhkan pencaharian mereka, yang lainnya lagi akan menimpali kata ndak bara beda doh 'tidak seberapa jauh' dengan yang lainnya bahwa ada juga yang kurang beruntung. 
(11) Pariuak bareh

sumber mata pencaharian

Pada data (11), paruik berarti periuk dan bareh adalah beras. Makna kontekstualnya bukanlah alat berupa peruik dan beras. Dalam konteks ini, pekerjaan sebagai sopir adalah mata pencaharian satu-satunya sopir untuk menghidupi diri sendiri dan keluarga.

(53) Tungga babeleang

satu-satunya

Data (53) tungga berarti tunggal, sedangkan babeleang berarti berputar di tempat. Makna kontekstualnya tidak berarti satu-satunya berputar pada sumbunya. Lebih ditekankan kepada angkot yang dimiliki sopir adalah sebagai harta atau barang berharga satu-satunya yang dipunyai sopir dalam kehidupannya..

\section{Penutup}

Penulis berharap agar penelitian ini tidak berhenti pada bentuk lingual, fungsi, dan makna dari graffiti berbahasa Minangkabau saja. Perkembangan zaman dan teknologi sangat mempengaruhi penggunaan bahasa yang digunakan. Maka dari itu, diharapkan penelitian sosiolinguistik ini dapat dilanjutkan pada nilai estetik dan ideologi penggunanya sampai kepada bahasa-bahasa lainnya. Agar lebih memadai untuk pengungkapan makna dan status sosial para pengguna graffiti secara keseluruhan oleh masyarakat Minangkabau.

Maksud tulisan para sopir dalam graffiti yang telah diterjemahkan, merupakan cermin dari pandangan hidup dan pandangan dunianya yang mereka gali dari pengalaman yang didapatkan baik sebagai individu maupun secara sosial. Pengalaman-pengalaman tersebut akhirnya membentuk persepsi-persepsi juga harapan. Persepsi-persepsi yang telah terbangun tadi mendorong terbentuknya pemikiran-pemikiran yang melahirkan tulisan yang memiliki kreatifitas bahasa yang tinggi.

Penulis menyadari kekurangsempurnaan dari penelitian ini. Namun, diharapkan manjadi dasar untuk dapat melakukan penelitian sosiolinguistik selanjutnya. Juga bermanfaat dan menjadi referensi yang berguna bagi pembaca, peminat linguistik khususnya sosiolinguistik, dan 
peneliti lainnya.

\section{Daftar Pustaka}

Agusti, Dwi Dheka. 2002. "Pragmatik dari Moris sampai Van Dijk" (laporan penelitian). Bandung: FPBS UPI.

Bambata. 2006. "Sejarah Graffiti" dalam Majalah HAI No 36/XXX/4 September - 10 September 2006.

Gumilang. 2008. “Graffiti sebagai Seni atau Pemberontakan?” dalam http:// www.petra.ac.id diakses tanggal 17 Juni 2008.

Levinson, Stephen C. 1987. Pragmatics. Cambridge: Cambridge University Press.

Lubis, Hamid Husain. 2007. Analisis Wacana Pragmatik. Medan: Badan Penerbit IKIP.

Mahsun. 2005. Metode Penelitian Bahasa: Tahapan Strategi, Metode, dan Tekniknya. Jakarta: PT Grafindo Persada.

Nababan, PWJ. 1993. Sosiolinguistik: Suatu Pengantar (cetakan ke-4). Jakarta: Balai Pustaka.

Sapir, Edwar. 1921. Language. New York: Hascourt, Brace \& World Inc. Sumarsono. 2002. Sosiolinguistik. Yogyakarta: Pustaka Pelajar.

Usman, Abdul Kadir. 2002. Kamus Umum Bahasa Minangkabau. Padang: Anggrek Media. 